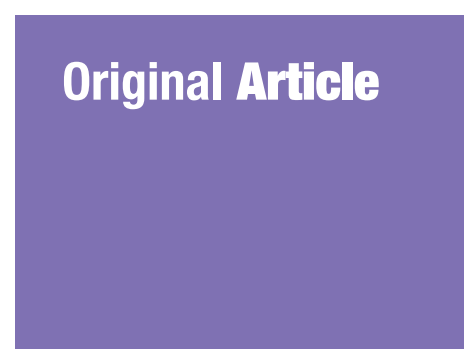

Submitted: 7 Aug 2018

Accepted: 2 Jun 2019

Online: 29 Aug 2019

\section{Zinc Supplementation and Ischemia Pre-conditioning in Renal Ischemia/ Reperfusion Injury}

\author{
Bahar Mazaheri', Fatemeh Emamı ${ }^{1}$, Fatemeh Moslemı', \\ Ardeshir Talebi ${ }^{1,2}$, Mehdi NematbaKhsh ${ }^{1,3,4}$ \\ 1 Water and Electrolytes Research Center, Isfahan University of Medical \\ Sciences, Isfahan, Iran \\ 2 Department of Clinical Pathology, Isfahan University of Medical Sciences, \\ Isfahan, Iran \\ 3 Department of Physiology, Isfahan University of Medical Sciences, Isfahan, \\ Iran \\ 4 Isfahan ${ }^{M N}$ Institute of Basic and Applied Sciences Research, Isfahan, Iran
}

To cite this article: Mazaheri B, Emami F, Moslemi F, Talebi A, Nematbakhsh M. Zinc supplementation and ischemia pre-conditioning in renal ischemia/reperfusion injury. Malays J Med Sci. 2019;26(4):39-46. https://doi.org/10.21315/mjms2019.26.4.5

To link to this article: https://doi.org/10.21315/mjms2019.26.4.5

\title{
Abstract
}

Backgrounds: Renal ischemia/reperfusion (RIR) is a major cause of kidney dysfunction in clinic. The main objective of this study was to investigate the effect of pre-conditioning ischemia (IPC) and zinc ( $\mathrm{Zn})$ supplementation on renal RIR injury.

Methods: A total of 63 unilateral nephrectomised male and female Wistar rats were divided into five groups. Group 1 (ShOPR): Rats as sham-operated group were subjected to surgical procedure without RIR. Group 2 (Isch): Rats underwent RIR (left kidney ischemia for 30 min followed by $48 \mathrm{~h}$ reperfusion). Group 3 ( $\mathrm{Zn}+\mathrm{Isch})$ : Rats were treated as group 2 but they received Zn sulphate $(30 \mathrm{mg} / \mathrm{kg}) 1 \mathrm{~h}$ before induction of RIR. Group 4 (IPC+Isch): Rats were treated as group 2 but they underwent $1 \mathrm{~min}$ of ischemia followed by 3 min reperfusion as IPC, which was repeated for three times before induction of RIR. Group $5(\mathrm{Zn}+\mathrm{IPC}+\mathrm{Isch})$ : Rats were subjected to receive both $\mathrm{Zn}$ sulphate and IPC before induction of RIR. Urine samples were collected in the last $6 \mathrm{~h}$ of reperfusion, and finally biochemical and histological measurements were performed.

Results: The serum level of creatinine (Cr), normalised kidney weight (KW) and kidney tissue damage score (KTDS) increased by RIR alone significantly $(P<0.05)$. These parameters were attenuated statistically by $\mathrm{Zn}$ supplementation $(P<0.05)$. However, IPC alone or cotreatment of $\mathrm{Zn}$ and IPC did not improve the biochemical and histological markers altered by RIR injury.

Conclusion: Zn supplementation had a protective role against RIR while such protective effect was not observed by IPC alone or by co-treatment of Zn and IPC.

Keywords: renal ischemia/reperfusion, zinc, pre-conditioning ischemia, nephrectomy, rat

\section{Introduction}

Renal ischemia/reperfusion (RIR) injury is a complex phenomenon, which disturbs renal function and induces kidney tissue damages $(1,2)$ resulting in acute kidney injury (AKI) (3).
Clinically, RIR injury is occurred in different circumstances such as renal transplantation, renal surgeries, post-resuscitation shock, complex cardiovascular surgeries, and chemical agents/drugs induced renal toxicity $(4,5)$. Renal transplantation induced RIR injury increases renal dysfunction and mortality rate $(3,5)$. 
In general, ischemia followed by reperfusion induces reactive oxygen species (ROS) formation and inflammation, oxidative stress, mitochondrial damage, and apoptosis, which all contribute to renal disorder $(3,4)$. In addition, it is well known that the rate, intensity, and prognosis of kidney disease and RIR injury are sex-related.

In past years, special attentions have been made to suggest clinical protocols and strategies to limit the RIR-induced kidney dysfunctions. Among these, antioxidants supplementation was more prominent, while pre-conditioning ischemia (IPC) strategy also was considered to protect the kidney against main RIR injury (6). In IPC strategy, the organ will be subjected to brief and sequential time periods ischemia/ reperfusion (IR) before the main ischemia will be performed; therefore the increased tissue resistance to IR will be resulted (7). The IPC efficacy depends on time and repeating sequence of IR. Although, the exact mechanism of this method is not fully documented, the reduction in inflammatory response and cellular apoptosis have been suggested as the proposed mechanism (8). The pharmacological IPC is also another interesting method in which chemical compounds will be used to suppress the inflammation and to increase antioxidant effect $(9,10)$, because during RIR injury, the activity of free radical scavenger enzymes such as superoxide dismutase (SOD), catalase (CAT), and glutathione peroxidase (GPx) play an important role to reduce ROS and tissue inflammation (11). Treatment with cobalt salts such as cobalt chloride $\left(\mathrm{CoCl}_{2}\right)$ has also shown protective effect on RIR injury (12). The optimal duration of IPC is extremely important, and the net definite optimal time has not been defined yet. In the study by Choi and colleagues, $3 \mathrm{~min}$, $5 \mathrm{~min}$ and $7 \mathrm{~min}$ of ischemia followed by $10 \mathrm{~min}$ of reperfusion as IPC was performed (3) while others used 4 min or 5 min of ischemia followed by $11 \mathrm{~min}$ or $5 \mathrm{~min}$ of reperfusion as IPC $(4,6,8)$. However; the shorter the time of IPC, the better would be the practice in the clinic. Therefore, in this study, we evaluated three cycles of $1 \mathrm{~min}$ ischemia followed by $3 \mathrm{~min}$ reperfusion.

Zinc $(\mathrm{Zn})$ is an essential element for the stability and activity of SOD, which its antioxidant effect was reported in RIR model $(13,14)$. Subcutaneous injection of $\mathrm{Zn}$ chloride also showed an intensive protective effect in reduction of tubular injury and necrosis. This trace element attenuated the increased serum levels of urea and creatinine $(\mathrm{Cr})$ induced by RIR injury $(13,15)$. Further studies may verify its essential protective role against RIR injury. Therefore, in the current study the effect of single dose of $\mathrm{Zn}$ and three cycles of $1 \mathrm{~min}$ ischemia followed by $3 \mathrm{~min}$ of reperfusion as IPC against RIR injury was evaluated.

\section{Materials and Methods}

\section{Animals}

To determine the sample size, the dependent variable of $\mathrm{Cr}$ was considered to compare the mean values between the groups. Based on a previous study (16), the mean difference between sham and RIR groups in serum $\mathrm{Cr}$ level was about $0.45(d=0.45)$ with standard deviation of $0.2(\sigma=0.2)$. The number of experimental groups in this study was five, and for two-tailed significance level of $0.05(\alpha=0.05, \mathrm{Z1}-\alpha / 2=1.96), 80 \%$ test power ( $\beta=0.2, \mathrm{Z} 1-\beta=0.80$ ), and using $\mathrm{G}^{*}$ Power software version 3.1.9.4 for one way ANOVA test, the total sample size was calculated as about 65 animals. Accordingly a total of 63 male and female rats were used in this study. These animals were randomly (by statistical random table) divided into five groups. Therefore, the experiment was conducted in 31 male (200 g-277 g) and 32 female (164 g-220 g) Wistar rats.

\section{Study Design}

The animals were anesthetised with chloral hydrate $(450 \mathrm{mg} / \mathrm{kg}$, intraperitoneally) (Merck, Germany) and the animals were subjected to right kidney nephrectomy. After one week of recovery, the rats were randomly divided into five experimental groups defined as the followings:

i. Group1 (called ShOPR, $n=7$ males and $n=8$ females): The rats were subjected to surgical procedure without RIR.

ii. Group 2 (called Isch, $n=6$ males and $n=7$ females): The animals were subjected to RIR surgery by an incision that was made on the abdominal skin, the left kidney was pulled out gently and the vessels were clamped for $30 \mathrm{~min}$ followed by $48 \mathrm{~h}$ reperfusion. 
Original Article | Zinc and ischemia pre-conditioning on renal injury

iii. Group 3 (called $\mathrm{Zn}+\mathrm{Isch}, n=7$ males and $n=5$ females): The rats received $\mathrm{Zn}$ sulphate $(30 \mathrm{mg} / \mathrm{kg})$ and after $1 \mathrm{~h}$ they were subjected to RIR as described for group 2.

iv. Group 4 (called IPC+Isch, $n=5$ males and $n=6$ females): The animals' renal vessels were clamped for 1 min followed by 3 min reperfusion, and this action was repeated three times (called IPC), then the animals were subjected to RIR as described for group 2.

v. Group 5 (called $\mathrm{Zn}+\mathrm{IPC}+\mathrm{Isch}, n=6$ males and $n=6$ females): The rats received $\mathrm{Zn}$ sulphate $(30 \mathrm{mg} / \mathrm{kg}) 1 \mathrm{~h}$ before they were subjected to IPC and RIR as described for group 4.

\section{Urine Collection}

All the rats were subjected to be kept in standard metabolic cage for urine collection in the last $6 \mathrm{~h}$ of reperfusion.

\section{Blood Samples and Measurements}

After $48 \mathrm{~h}$ of reperfusion, the animals were anesthetised again, and the blood samples were taken via heart puncture, and the sera were stored in $-20{ }^{\circ} \mathrm{C}$. The serum and urine levels of $\mathrm{Cr}$ were determined using quantitative diagnostic kits (Pars Azmoon, Iran) and automatic analyzer RA-1000 (Technicon, Ireland). The urine and plasma sodium concentrations were measured by phlamephotomer assay.

The sample of each kidney was fixed in $10 \%$ formalin for hematoxylin-eosin (H\&E) staining to determine the kidney tissue damage score (KTDS) by a pathologist who was blinded to the study protocol. The serum levels of malondialdehyde (MDA) and nitrite (Greiss Method) were measured. The clearance $\mathrm{Cr}$ $(\mathrm{ClCr})$, urine flow rate (UF), and the percentage of excretion $\mathrm{Na}$ fraction (ENa fraction) were also determined.

\section{Statistical Analysis}

The data were reported as mean $\pm(\mathrm{SD})$. One-way ANOVA test was used to analyse the data. Mann-Whitney or Kruskal-Wallis tests were applied to compare the KTDS between the groups.

\section{Results}

The results revealed that the serum level of $\mathrm{Cr}$ increased significantly in Isch group compared with ShOPR group $(P<0.05)$. In $\mathrm{Zn}+$ Isch group, the serum level of $\mathrm{Cr}$ decreased significantly compared with Isch group $(P=0.004)$ (Table 1$)$, and such finding was not seen in IPC+Isch and $\mathrm{Zn}+\mathrm{IPC}+\mathrm{Isch}$ groups. The left kidney weight (KW) showed significant increment in all Isch groups compared with ShOPR group, however this parameter in IPC+Isch+Zn group was increased significantly compared with Isch group $(P<0.05)$ (Table 2$)$. The results of KTDS indicated that kidney injury increased significantly in Isch groups compared with ShOPR group $(P<0.05)$ and $\mathrm{Zn}$ supplementation improved kidney injury significantly in $\mathrm{Zn}+\mathrm{Isch}$ group compared with Isch group $(P<0.05)$ (Table 3$)$.

Although the $\mathrm{ClCr}$ was decreased in IPC+Isch group compared with ShOPR group and it was increased in $\mathrm{Zn}+\mathrm{IPC}+\mathrm{Isch}$ group compared with Isch group, these changes were not significant (Table 4). The ENa fraction in $\mathrm{Zn}+\mathrm{IPC}+\mathrm{Isch}$ group decreased insignificantly

Table 1. Comparison of mean serum levels of Cr between the five groups

\begin{tabular}{|c|c|c|c|c|c|c|c|c|}
\hline Groups & $n$ & $\begin{array}{c}\text { Creatinine } \\
\text { (mg/dL) } \\
\text { Mean (SD) }\end{array}$ & $\begin{array}{c}F \text {-statistic } \\
\text { (df1, df2) }\end{array}$ & $P$-value & $\begin{array}{l}\text { Group } \\
\text { versus } \\
\text { ShOPR }\end{array}$ & $\begin{array}{c}\text { Group } \\
\text { versus } \\
\text { Isch }\end{array}$ & $\begin{array}{c}\text { Group } \\
\text { versus } \\
\text { Zn+Isch }\end{array}$ & $\begin{array}{c}\text { Group } \\
\text { versus } \\
\text { IPC+Isch }\end{array}$ \\
\hline ShOPR & 15 & $0.76(0.11)$ & \multirow{5}{*}{$\begin{array}{c}4.52 \\
(4,58)\end{array}$} & \multirow{5}{*}{0.004} & - & - & - & - \\
\hline Isch & 13 & $0.95(0.18) *$ & & & 0.002 & - & - & - \\
\hline $\mathrm{Zn}+\mathrm{Isch}$ & 12 & $0.80(0.14)^{\dagger}$ & & & 0.490 & 0.019 & - & - \\
\hline IPC+Isch & 11 & $0.96(0.16) *$ & & & 0.001 & 0.834 & 0.014 & - \\
\hline $\mathrm{Zn}+\mathrm{IPC}+\mathrm{Isch}$ & 12 & $0.90(0.12) *$ & & & 0.024 & 0.403 & 0.127 & 0.314 \\
\hline
\end{tabular}

One-way ANOVA, post-hoc LSD analysis shows significant difference between groups. The asterisk $\left(^{*}\right)$ indicates significant difference in Isch, IPC+Isch, $\mathrm{Zn}+\mathrm{IPC}+\mathrm{Isch}$ from ShOPR group $(P=0.002, P=0.001$ and $P=0.024$, respectively $)$ and the symbol $(\dagger)$ indicates from Isch group $(P=0.019)$ 
Table 2. Comparison of mean KW between the five groups

\begin{tabular}{|c|c|c|c|c|c|c|c|c|}
\hline Groups & $n$ & $\begin{array}{c}\text { KW(g)/10ogBW } \\
\text { Mean (SD) }\end{array}$ & $\begin{array}{c}\text { F-statistic } \\
\text { (df1, df2) }\end{array}$ & $P$-value & $\begin{array}{l}\text { Group } \\
\text { versus } \\
\text { ShOPR }\end{array}$ & $\begin{array}{c}\text { Group } \\
\text { versus } \\
\text { Isch }\end{array}$ & $\begin{array}{c}\text { Group } \\
\text { versus } \\
\text { Zn+Isch }\end{array}$ & $\begin{array}{c}\text { Group } \\
\text { versus } \\
\text { IPC+Isch }\end{array}$ \\
\hline ShOPR & 15 & $0.45(0.04)$ & \multirow{5}{*}{$\begin{array}{c}6.99 \\
(4,57)\end{array}$} & \multirow{5}{*}{$<0.001$} & - & - & - & - \\
\hline Isch & 13 & $0.55(0.06)^{*}$ & & & $<0.001$ & - & - & - \\
\hline $\mathrm{Zn}+\mathrm{Isch}$ & 12 & $0.51(0.05)^{*}$ & & & 0.002 & 0.099 & - & - \\
\hline IPC+Isch & 11 & $0.51(0.05)^{*}$ & & & 0.004 & 0.093 & 0.912 & - \\
\hline $\mathrm{Zn}+\mathrm{IPC}+\mathrm{Isch}$ & 12 & $0.49(0.04)^{* \dagger}$ & & & 0.042 & 0.007 & 0.271 & 0.347 \\
\hline
\end{tabular}

One-way ANOVA, Post-hoc LSD analysis shows significant difference between groups. The asterisk $(*)$ indicates significant difference in Isch, $\mathrm{Zn}+\mathrm{Isch}$, IPC+Isch, $\mathrm{Zn}+\mathrm{IPC}+\mathrm{Isch}$ from ShOPR group $(P=<0.001, P=0.002, P=0.004$ and $P=0.042$, respectively) and the symbol $(\dagger)$ indicates from Isch group $(P=0.007)$

Table 3. Comparison of mean KTDS between the five groups

\begin{tabular}{|c|c|c|c|c|c|c|c|c|}
\hline Groups & $\boldsymbol{n}$ & $\begin{array}{c}\text { KTDS } \\
\text { Mean (SD) }\end{array}$ & $\begin{array}{c}\text { Test } \\
\text { statistic } \\
\text { (df) }\end{array}$ & $P$-value & $\begin{array}{l}\text { Group } \\
\text { versus } \\
\text { ShOPR }\end{array}$ & $\begin{array}{c}\text { Group } \\
\text { versus } \\
\text { Isch }\end{array}$ & $\begin{array}{c}\text { Group } \\
\text { versus } \\
\text { Zn+Isch }\end{array}$ & $\begin{array}{c}\text { Group } \\
\text { versus } \\
\text { IPC+Isch }\end{array}$ \\
\hline ShOPR & 15 & $0.8(0.41)$ & \multirow{5}{*}{$\begin{array}{l}33.83 \\
(4)\end{array}$} & \multirow{5}{*}{$<0.001$} & - & - & - & - \\
\hline Isch & 12 & $2.16(0.38)^{*}$ & & & $<0.001$ & - & - & - \\
\hline $\mathrm{Zn}+\mathrm{Isch}$ & 12 & $1.41(0.51)^{* \dagger}$ & & & 0.004 & 0.002 & - & - \\
\hline IPC+Isch & 10 & $2.10(0.31)^{*}$ & & & 0.000 & 0.658 & 0.003 & - \\
\hline $\mathrm{Zn}+\mathrm{IPC}+\mathrm{Isch}$ & 11 & $2.00(0.89)^{*}$ & & & 0.001 & 0.630 & 0.101 & 0.782 \\
\hline
\end{tabular}

The Mann-Whitney or Kruskal-Wallis analysis shows significant difference between groups. The asterisk $\left.{ }^{*}\right)$ indicates significant difference in Isch, $\mathrm{Zn}+\mathrm{Isch}$, IPC+Isch and $\mathrm{Zn}+\mathrm{IPC}+\mathrm{Isch}$ from ShOPR group $(P<0.001, P=0.004, P<0.001, P=0.001)$ and the symbol $(\dagger)$ indicates from Isch group $(P=0.002)$

Table 4. Comparison of mean $\mathrm{ClCr}$ between the five groups

\begin{tabular}{lcccccccc} 
Groups & $\boldsymbol{n}$ & $\begin{array}{c}\text { ClCr }(\mu \mathrm{L} / \\
\text { min/g tissue) } \\
\text { Mean (SD) }\end{array}$ & $\begin{array}{c}F \text {-statistic } \\
\text { (df1 ,df2) }\end{array}$ & P-value & $\begin{array}{c}\text { Group } \\
\text { versus } \\
\text { ShOPR }\end{array}$ & $\begin{array}{c}\text { Group } \\
\text { versus } \\
\text { Isch }\end{array}$ & $\begin{array}{c}\text { Group } \\
\text { versus } \\
\text { Zn+Isch }\end{array}$ & $\begin{array}{c}\text { Group } \\
\text { versus } \\
\text { IPC+Isch }\end{array}$ \\
ShOPR & 15 & $82.00(40.28)$ & & & - & - & - & - \\
Isch & 13 & $60.43(28.93)$ & 1.19 & & 0.147 & - & - & - \\
Zn+Isch & 12 & $78.85(41.71)$ & $(4,56)$ & 0.162 & 0.834 & 0.232 & - & - \\
IPC+Isch & 11 & $59.05(45.62)$ & & & 0.151 & 0.931 & 0.230 & - \\
Zn+IPC+Isch & 12 & $83.68(33.27)$ & & & 0.911 & 0.133 & 0.757 & 0.136 \\
\hline
\end{tabular}

One-way ANOVA, Post-hoc LSD analysis shows no significant difference between groups

compared with ShOPR or Isch group (Table 5). No significant difference was found in urine flow (UF) rate between the groups (Table 6). The results related to the serum levels of MDA and nitrite showed no significant differences between the groups (Tables 7 and 8). The kidney tissue images of all the experimental groups are demonstrated in Figure 1. More damages were observed in Isch, IPC and $\mathrm{Zn}+\mathrm{IPC}+\mathrm{Isch}$ groups compared with ShOPR group.

\section{Discussion}

The main purpose of this study was to determine the protective effect of $\mathrm{Zn}$ and IPC in RIR injury. The results showed that $\mathrm{Zn}$ supplementation protects the kidney against RIR injury, while IPC implementation and co-treatment of $\mathrm{Zn}$ and IPC did not show such a protective effect. The RIR injury may activate some pathological pathways such as 
Original Article | Zinc and ischemia pre-conditioning on renal injury

Table 5. Comparison of mean excretion Na fraction (ENa fraction) between the five groups

\begin{tabular}{|c|c|c|c|c|c|c|c|c|}
\hline Groups & $n$ & $\begin{array}{c}\text { ENa Fraction } \\
\text { (\%) } \\
\text { Mean (SD) }\end{array}$ & $\begin{array}{l}\text { F-statistic } \\
\text { (df1 ,df2) }\end{array}$ & $P$-value & $\begin{array}{l}\text { Group } \\
\text { versus } \\
\text { ShOPR }\end{array}$ & $\begin{array}{l}\text { Group } \\
\text { versus } \\
\text { Isch }\end{array}$ & $\begin{array}{l}\text { Group } \\
\text { versus } \\
\mathrm{Zn}+\text { Isch }\end{array}$ & $\begin{array}{l}\text { Group } \\
\text { versus } \\
\text { IPC+Isch }\end{array}$ \\
\hline ShOPR & 15 & $0.70(0.35)$ & \multirow{5}{*}{$\begin{array}{c}0.96 \\
(4,53)\end{array}$} & \multirow{5}{*}{0.432} & - & - & - & - \\
\hline Isch & 13 & $0.69(0.45)$ & & & 0.937 & - & - & - \\
\hline $\mathrm{Zn}+\mathrm{Isch}$ & 12 & $0.63(0.52)$ & & & 0.722 & 0.784 & - & - \\
\hline IPC+Isch & 11 & $0.78(0.81)$ & & & 0.736 & 0.686 & 0.514 & - \\
\hline $\mathrm{Zn}+\mathrm{IPC}+\mathrm{Isch}$ & 12 & $0.34(0.46)$ & & & 0.114 & 0.136 & 0.222 & 0.078 \\
\hline
\end{tabular}

One-way ANOVA, Post-hoc LSD analysis shows no significant difference between groups

Table 6. Comparison of mean UF between the five groups

\begin{tabular}{|c|c|c|c|c|c|c|c|c|}
\hline Groups & $n$ & $\begin{array}{c}\text { UF }(\mu \mathrm{L} / \mathrm{min} / \mathrm{g} \\
\text { tissue) } \\
\text { Mean (SD) }\end{array}$ & $\begin{array}{l}F \text {-statistic } \\
\text { (df1 ,df2) }\end{array}$ & $P$-value & $\begin{array}{l}\text { Group } \\
\text { versus } \\
\text { ShOPR }\end{array}$ & $\begin{array}{l}\text { Group } \\
\text { versus } \\
\text { Isch }\end{array}$ & $\begin{array}{c}\text { Group } \\
\text { versus } \\
\mathrm{Zn}+\text { Isch }\end{array}$ & $\begin{array}{c}\text { Group } \\
\text { versus } \\
\text { IPC+Isch }\end{array}$ \\
\hline ShOPR & 15 & $0.84(0.61)$ & \multirow{5}{*}{$\begin{array}{c}0.45 \\
(4,56)\end{array}$} & \multirow{5}{*}{0.770} & - & - & - & - \\
\hline Isch & 13 & $0.59(0.27)$ & & & 0.207 & - & - & - \\
\hline $\mathrm{Zn}+\mathrm{Isch}$ & 12 & $0.77(0.46)$ & & & 0.742 & 0.370 & - & - \\
\hline IPC+Isch & 11 & $0.70(0.37)$ & & & 0.503 & 0.615 & 0.728 & - \\
\hline $\mathrm{Zn}+\mathrm{IPC}+\mathrm{Isch}$ & 12 & 0.76 (o.69) & & & 0.704 & 0.397 & 0.960 & 0.764 \\
\hline
\end{tabular}

One-way ANOVA, Post-hoc LSD analysis shows no significant difference between groups

Table 7. Comparison of mean serum levels of MDA between the five groups

\begin{tabular}{|c|c|c|c|c|c|c|c|c|}
\hline Groups & $n$ & $\begin{array}{c}\text { MDA } \\
\text { ( } \mathrm{mmole} / \mathrm{L}) \\
\text { Mean (SD) }\end{array}$ & $\begin{array}{l}\text { F-statistic } \\
\text { (df1, df2) }\end{array}$ & $P$-value & $\begin{array}{c}\text { Group } \\
\text { versus } \\
\text { ShOPR }\end{array}$ & $\begin{array}{c}\text { Group } \\
\text { versus } \\
\text { Isch }\end{array}$ & $\begin{array}{c}\text { Group } \\
\text { versus } \\
\mathbf{Z n}+\text { Isch }\end{array}$ & $\begin{array}{c}\text { Group } \\
\text { versus } \\
\text { IPC+Isch }\end{array}$ \\
\hline ShOPR & 15 & $9.26(2.73)$ & \multirow{5}{*}{$\begin{array}{c}0.76 \\
(4,56)\end{array}$} & \multirow{5}{*}{0.556} & - & - & - & - \\
\hline Isch & 13 & $11.11(2.61)$ & & & 0.164 & - & - & - \\
\hline $\mathrm{Zn}+\mathrm{Isch}$ & 12 & $9.56(3.91)$ & & & 0.821 & 0.261 & - & - \\
\hline IPC+Isch & 11 & $10.90(3.37)$ & & & 0.238 & 0.879 & 0.352 & - \\
\hline $\mathrm{Zn}+\mathrm{IPC}+\mathrm{Isch}$ & 12 & $9.71(4.35)$ & & & 0.744 & 0.320 & 0.918 & 0.417 \\
\hline
\end{tabular}

One-way ANOVA, Post-hoc LSD analysis shows no significant difference between groups

Table 8. Comparison of mean serum levels of nitrite between the five groups

\begin{tabular}{|c|c|c|c|c|c|c|c|c|}
\hline Groups & $n$ & $\begin{array}{c}\text { Nitrite } \\
\text { ( } \text { umole/L) } \\
\text { Mean (SD) }\end{array}$ & $\begin{array}{l}\text { F-statistic } \\
\text { (df1, df2) }\end{array}$ & $P$-value & $\begin{array}{l}\text { Group } \\
\text { versus } \\
\text { ShOPR }\end{array}$ & $\begin{array}{c}\text { Group } \\
\text { versus } \\
\text { Isch }\end{array}$ & $\begin{array}{c}\text { Group } \\
\text { versus } \\
\text { Zn+Isch }\end{array}$ & $\begin{array}{c}\text { Group } \\
\text { versus } \\
\text { IPC+Isch }\end{array}$ \\
\hline ShOPR & 15 & $4.42(1.79)$ & \multirow{5}{*}{$\begin{array}{c}0.39 \\
(4,57)\end{array}$} & \multirow{5}{*}{0.814} & - & - & - & - \\
\hline Isch & 13 & $4.56(1.86)$ & & & 0.875 & - & - & - \\
\hline $\mathrm{Zn}+\mathrm{Isch}$ & 12 & $5.05(1.89)$ & & & 0.486 & 0.593 & - & - \\
\hline IPC+Isch & 11 & $5 \cdot 35(3.20)$ & & & 0.317 & 0.402 & 0.755 & - \\
\hline $\mathrm{Zn}+\mathrm{IPC}+\mathrm{Isch}$ & 12 & $5.18(2.55)$ & & & 0.401 & 0.500 & 0.890 & 0.859 \\
\hline
\end{tabular}

One-way ANOVA, Post-hoc LSD analysis shows no significant difference between groups 
neutrophils activation, and ROS releasing, and promotes other inflammatory process, which all cause kidney tissue damage (17). Inflammatory mediators lead to disturb the epithelial cells and decrease renal blood flow $(1,18)$. It is also expected that the RIR injury induced inflammation may increase $\mathrm{KW}$ as Afyouni and colleagues demonstrated that KW increased in RIR injury model (19). A model of IPC, in which bilateral renal pedicles were clipped for 5 min followed by 5 min reperfusion for three times, resulted in an improvement of renal injury (20). Such improvement was not obtained in our experiment. This discrepancy between our results and other findings may be related to vessel closure duration to induce IPC. Possibly the $1 \mathrm{~min}$ vessel clamp followed by 3 min reperfusion repeated for three times was not completely enough to prepare the kidney for the main RIR since it is reported that $5 \mathrm{~min}$ IPC performed the best protective effect against RIR injury (3). Also the kidney cortex blood flow is directly under the influence of renal artery blood flow, but the renal medulla blood flow is slightly different. It is reported that oxygen disappearance rate during complete kidney ischemia is different between renal cortex and medulla (21), and the outer medulla hypoxia may remain during reperfusion after RIR (22). Therefore, we may assume that $1 \mathrm{~min}$ closure of the kidney vessels may not be adapted for the whole kidney against major RIR. Accordingly, a longer ischemia time is suggested to have an efficient IPC (3, 20, 23).

$\mathrm{Zn}$ as a protective agent against RIR was studied before, and it was shown that $\mathrm{Zn}$ improved RIR injury (14, 24, 25). Possibly, the antioxidant effect of $\mathrm{Zn}$ (26) is the major cause of this protection since $\mathrm{Zn}$ increases metallothionein production, which scavenges free radicals $(\mathrm{OH})(27)$ and $\mathrm{Zn}$ deficiency disturbs lipid peroxidation system (28). Barekat and colleagues reported that $\mathrm{Zn}$ protected the kidney against RIR in ovariectomised rats (24) while the protective role of $\mathrm{Zn}$ against RIR injury reported to be sex-related (29). On the contrary, co-treatment of $\mathrm{Zn}$ and IPC did not protect the kidney against RIR. At this time, there is no interpretation for such finding, but the interaction between $\mathrm{Zn}$ and IPC may abolish the protective effect of $\mathrm{Zn}$ alone as it was demonstrated in $\mathrm{Zn}+$ Isch group.

\section{Conclusion}

The model of IPC in this study did not protect the kidney against ischemia. However, a single dose of $\mathrm{Zn}$ administration before RIR improves RIR injury. But IPC accompanied by Zn did not protect the kidney against RIR injury with unknown mechanism.

\section{Acknowledgements}

This research was supported by Isfahan University of Medical Sciences (grants number 296096 \& 296099).

\section{Ethics of Study}

The study protocol was approved by the Ethics Committee of Isfahan University of Medical Sciences (code: IR.MUI. REC1396.2.099).

\section{Conflict of Interest}

None.

\section{Funds}

None.

\section{Authors' Contributions}

Conception and design: $\mathrm{MN}$

Analysis and interpretation of the data: BM, MN

Drafting of the article: BM, FE, FM

Critical revision of the article for important intellectual content: MN

Final approval of the article: MN

Provision of study materials or patients: BM, FE, FM, AT

Obtaining of funding: MN

Administrative, technical, or logistic support: MN

Collection and assembly of data: BM, FE, FM, AT

\section{Correspondence}

Dr Mehdi Nematbakhsh

$\mathrm{PhD}$ (Louisiana Tech University, USA)

Water and Electrolytes Research Center,

Isfahan University of Medical Sciences,

Isfahan 81745, Iran.

Tel: +98 03137929019

Fax: +98 03137929019

E-mail: nematbakhsh@med.mui.ac.ir,nematbakhsh@ gmail.com 
Original Article | Zinc and ischemia pre-conditioning on renal injury

\section{References}

1. Bonventre JV, Yang L. Cellular pathophysiology of ischemic acute kidney injury. $J$ Clin Invest. 2011;121(11):4210-4221. https://doi.org/10. 1172/JCI45161

2. Noiri E, Nakao A, Uchida K, Tsukahara H, Ohno M, Fujita T, et al. Oxidative and nitrosative stress in acute renal ischemia. Am $J$ Physiol Renal Physiol. 2001;281(5):F948-F957. https://doi. org/10.1152/ajprenal.2001.281.5.F948

3. Choi HS, Hwang JK, Kim JG, Hwang HS, Lee SJ, Chang YK, et al. The optimal duration of ischemic preconditioning for renal ischemiareperfusion injury in mice. Ann Surg Treat Res. 2017;93(4):209-216. https://doi.org/10.4174/ astr.2017.93.4.209

4. Chen YT, Wallace CG, Yang CC, Chen CH, Chen KH, Sung PH, et al. DPP-4 enzyme deficiency protects kidney from acute ischemiareperfusion injury: role for remote intermittent bowel ischemia-reperfusion preconditioning. Oncotarget. 2017;8(33):54821-54837. https:// doi.org/10.18632/oncotarget.18962

5. Hussein AM, Barakat N, Awadalla A, Gabr MM, Khater S, Harraz AM, et al. Modulation of renal ischemia/reperfusion in rats by a combination of ischemic preconditioning and adipose-derived mesenchymal stem cells (ADMSCs). Can J Physiol Pharmacol. 2016;94(9):936-946. https://doi. org/10.1139/cjpp-2016-0018

6. Ebrahimi SM, Aboutaleb N, Nobakht M. Consequences of ischemic preconditioning of kidney: comparing between male and female rats. Iran J Basic Med Sci. 2012;15(6):1148-1153.

7. Yoon YE, Lee KS, Choi KH, Kim KH, Yang SC, Han WK. Preconditioning strategies for kidney ischemia reperfusion injury: implications of the "time-window" in remote ischemic preconditioning. PLoS One. 2015;10(4):e0124130. https://doi.org/10.1371/ journal.pone.0124130

8. Mahfoudh-Boussaid A, Zaouali MA, Hadj-Ayed K, Miled AH, Saidane-Mosbahi D, RoselloCatafau J, et al. Ischemic preconditioning reduces endoplasmic reticulum stress and upregulates hypoxia inducible factor-1alpha in ischemic kidney: the role of nitric oxide. $J$ Biomed Sci. 2012;19:7. https://doi.org/10.1186/1423-0127-197
9. Gao D, Jing S, Zhang Q, Wu G. Pterostilbene protects against acute renal ischemia reperfusion injury and inhibits oxidative stress, inducible nitric oxide synthase expression and inflammation in rats via the Toll-like receptor 4/nuclear factor- $\mathrm{kB}$ signaling pathway. Exp Ther Med. 2018;15(1):1029-1035. https://doi. org/10.3892/etm.2017.5479

10. Choucry MA, Khalil MN, El Awdan SA. Protective action of Crateva nurvala Buch. Ham extracts against renal ischaemia reperfusion injury in rats via antioxidant and anti-inflammatory activities. $J$ Ethnopharmacol. 2018;214:47-57. https://doi. org/10.1016/j.jep.2017.11.034

11. Akcil E, Tug T, Doseyen Z. Antioxidant enzyme activities and trace element concentrations in ischemia-reperfusion. Biol Trace Elem Res. 2000;76(1):13-17. https://doi.org/10.1385/ BTER:76:1:13

12. Matsumoto $\mathrm{M}$, Makino $\mathrm{Y}$, Tanaka $\mathrm{T}$, Tanaka $\mathrm{H}$, Ishizaka $\mathrm{N}$, Noiri $\mathrm{E}$, et al. Induction of renoprotective gene expression by cobalt ameliorates ischemic injury of the kidney in rats. J Am Soc Nephrol. 2003;14(7):1825-1832. https://doi.org/10.1097/01.ASN.0000074239. 022357.06

13. Ogawa T, Mimura Y. Antioxidant effect of zinc on acute renal failure induced by ischemia-reperfusion injury in rats. $A m J$ Nephrol. 1999;19(5):609-614. https://doi. org/10.1159/000013529

14. Abdallah NH, Baulies A, Bouhlel A, Bejaoui M, Zaouali MA, Mimouna SB, et al. The effect of zinc acexamate on oxidative stress, inflammation and mitochondria induced apoptosis in rat model of renal warm ischemia. Biomed Pharmacother. 2018;105:573-581. https://doi.org/10.1016/j. biopha.2018.06.017

15. Rao K, Sethi K, Ischia J, Gibson L, Galea L, Xiao $\mathrm{L}$, et al. Protective effect of zinc preconditioning against renal ischemia reperfusion injury is dose dependent. PLoS One. 2017;12(7):e0180028. https://doi.org/10.1371/journal.pone.0180028

16. Azarkish F, Nematbakhsh M, Fazilati M, Talebi A, Pilehvarian AA, Pezeshki Z, et al. N-acetylcysteine prevents kidney and lung disturbances in renal ischemia/reperfusion injury in rat. Int $J$ Prev Med. 2013;4:1139-1146. 
17. Malek M, Nematbakhsh M. Renal ischemia/ reperfusion injury; from pathophysiology to treatment. J Renal Inj Prev. 2015;4(2):20-27. https://doi.org/10.12861/jrip.2015.06

18. Sheridan AM, Bonventre JV. Cell biology and molecular mechanisms of injury in ischemic acute renal failure. Curr Opin Nephrol Hypertens. 2000;9(4):427-434.

19. Afyouni NE, Halili H, Moslemi F, Nematbakhsh M, Talebi A, Shirdavani S, et al. Preventive role of endothelin antagonist on kidney ischemia: Reperfusion injury in male and female rats. Int $J$ Prev Med. 2015;6:128. https://doi. org/10.4103/2008-7802.172549

20. Kierulf-Lassen C, Kristensen MLV, Birn H, Jespersen B, Nørregaard R. No effect of remote ischemic conditioning strategies on recovery from renal ischemia-reperfusion injury and protective molecular mediators. PLoS One. 2015;10(12):e0146109. https://doi.org/o.1371/ journal.pone.0146109

21. Nematbakhsh M, Eppel GA, Goddard D, O'Connor PM, Evans RG. Local maximum oxygen disappearance rate has limited utility as a measure of local renal tissue oxygen consumption. $J$ Pharmacol Toxicol Methods. 2010;61(3):297303. https://doi.org/10.1016/j.vascn.2010.01.007

22. Abdelkader A, Ho J, Ow CP, Eppel GA, Rajapakse NW, Schlaich MP, et al. Renal oxygenation in acute renal ischemia-reperfusion injury. $A m J$ Physiol Renal Physiol. 2014;306(9):F1026F1038. https://doi.org/10.1152/ajprenal.oo281. 2013

23. Balci C, Akan M, Boztas N, Ozkardesler S, Ergur BU, Guneli ME, et al. Protective effects of dexmedetomidine and remote ischemic preconditioning on renal ischemia reperfusion injury in rats. Ulus Travma Acil Cerrahi Derg. 2017;23(4):279-286. https://doi.org/10.5505/ tjtes.2016.49103
24. Barekat F, Talebi A, Nematbakhsh M. The protective roles of zinc and estradiol in renal ischemia/reperfusion injury in ovariectomized rats. J Nephropathol. 2018;7(2):88-92. https:// doi.org/10.15171/jnp.2018.21

25. Hadj Abdallah N, Baulies A, Bouhlel A, Bejaoui M, Zaouali MA, Ben Mimouna S, et al. Zinc mitigates renal ischemia-reperfusion injury in rats by modulating oxidative stress, endoplasmic reticulum stress, and autophagy. $J$ Cell Physiol. 2018;223(11):8677-8690. https://doi.org/10. 1002/jcp.26747

26. Zago MP, Oteiza PI. The antioxidant properties of zinc: interactions with iron and antioxidants. Free Radic Biol Med. 2001;31(2):266-274.

27. Prasad AS, Bao B, Beck FW, Kucuk O, Sarkar FH. Antioxidant effect of zinc in humans. Free Radic Biol Med. 2004;37(8):1182-1190. https://doi. org/10.1016/j.freeradbiomed.2004.07.007

28. Bicer M, Gunay M, Baltaci AK, Uney K, Mogulkoc R, Akil M. Effect of zinc supplementation on lipid peroxidation and lactate levels in rats with diabetes induced by streptozotocin and subjected to acute swimming exercise. Bratisl Lek Listy. 2012;113(4):199-205. https://doi.org/10.4149/ BLL_2012_046

29. Moslemi F, Talebi A, Nematbakhsh M. The protective effect of zinc supplementation on renal ischemia/reperfusion injury in rat: gender-related difference. Int J Prev Med. 2019;10:68. https:// doi.org/10.4103/ijpvm.IJPVM_279_17 